\title{
RANCANG BANGUN ALAT HITUNG ELEKTRONIK SEDERHANA UNTUK TUNA NETRA MENGGUNAKAN KONVERSI TEKS KE SUARA DENGAN ISD 2590
}

\author{
Mochammad Iqbal ${ }^{1}$, Muhamad Yusuf ${ }^{2}$ \\ ${ }^{1,2}$ Program Studi Teknik Elektronika - Politeknik Negeri Cilacap \\ muhamad.yusuf.1986@gmail.com
}

\begin{abstract}
People with special needs need to get equality in the use of technology. One is technological tools such as a calculator to count. Calculator is a tool for human arithmetic, but in reality not all the calculators can be used in humans. Lack of facilities for blind persons is difficult for them in the process of calculations using the calculator. Need to develop a calculator that can petrify blind persons to perform the calculation process. By using the voice of the speaker via a series of ISD 2590, ATmega16 as the main control, 4x4 keypad as number operations, $2 x 16$ LCD as a viewer of the results of operations of numbers, and Braille, it creates tools for the blind count. From the results of testing the system as a whole, these tools can only perform number operations as addition, subtraction, multiplication, and division. This tool can also operate for the fractions and round.
\end{abstract}

Keywords: 2x16 LCD, ATmega16, ISD2590, Keypad 4x4, Speaker

\section{INTISARI}

Orang yang berkebutuhan khusus perlu mendapatkan kesetaraan dalam hal penggunaan teknologi. Salah satunya adalah teknologi alat berhitung seperti kalkulator. Kalkulator merupakan alat bantu hitung bagi manusia, namun dalam kenyataan tidak semua kalkulator bisa digunakan pada manusia. Kurangnya fasilitas bagi penyandang tuna netra menyulitkan mereka dalam melakukan proses perhitungan menggunakan kalkulator. Perlu dikembangkan sebuah kalkulator yang dapat membatu penyandang tuna netra untuk melakukan proses perhitungan. Dengan menggunakan bunyi suara dari speaker melalui rangkaian ISD 2590, ATmega16 sebagai kendali utama, keypad 4x4 sebagai operasi bilangan, LCD $2 \times 16$ sebagai penampil dari hasil dari operasi bilangan, dan huruf braille, maka terciptalah alat bantu hitung bagi tuna netra. Dari hasil pengujian sistem secara keseluruhan, alat ini hanya bisa melakukan operasi bilangan penjumlahan, pengurangan, perkalian, dan pembagian. Alat ini juga dapat beroperasi untuk pada bilangan pecahan maupun bulat.

Kata Kunci: ATmega16, Keypad 4x4, ISD 2590, LCD 2x16, Speaker

\section{PENDAHULUAN}

Kalkulator merupakan alat bantu yang efektif untuk melakukan proses perhitungan. Kalkulator dapat digunakan kapan saja dan di mana saja karena sangat mudah di bawa. Pada umumnya banyak macam kalkulator yang digunakan oleh setiap orang, mulai dari kalkulator sederhana sampai kalkulator ilmiah. Kalkulator sederhana biasa digunakan untuk perhitungan umum seperti penjumlahan, pengurangan, perkalian dan pembagian. Sedangkan kalkulator ilmiah digunakan untuk perhitungan biasa dan juga perhitungan yang rumit seperti perhitungan akar, sinus, cosinus, tan dan sebagainya.

Kalkulator pada umumnya tidak mengeluarkan suara, hanya memunculkan angka perhitungan pada layar LCD, sehingga tidak semua orang bisa menggunakan kalkulator tersebut, terutama pada penyandang tuna netra. Kalkutor biasa, sulit digunakan oleh penyandang tuna netra dan mereka membutuhkan kalkulator khusus yang mampu mempermudah untuk melakukan proses perhitungan. Namun di pasaran masih belum ada kalkulator yang mampu memudahkan mereka untuk melakukan proses perhitungan. Kalkulator yang mampu 
mengeluarkan suara adalah solusi yang tepat untuk mereka dalam melakukan proses perhitungan dengan menggunakan kalkulator.

Dari hasil penelitian sebelumnya yang dilakukan oleh Muhammad [8] alat ini masih memiliki beberapa aspek kelemahan yakni, belum menggunakan baterai internal, sistem perhitungan hanya mencapai 7 digit, serta masih perlu adanya penelitian lebih lanjut guna mengetahui sistem, unjuk kerja, dan tingkat kelayakan alat tersebut.

Dari beberapa hal di atas maka penulis mengambil judul Kalkulator sederhana khusus penyandang tuna netra menggunakan huruf braille dengan output suara. Kelebihan kalkulator ini menggunakan bahasa Indonesia dan angka / keypad braille, sehingga memudahkan penyandang tuna netra untuk melakukan proses perhitungan.

Adapun tujuan dari penelitian ini adalah memodifikasi keypad 4x4 menjadi angka braille sebagai masukan dan membuat kalkulator suara untuk tuna netra menggunakan ISD 2590. Berdasarkan uraian permasalahan pada latar belakang masalah, maka perumusan masalah yang akan dibahas adalah bagaimana cara memodifikasi keypad 4x4 menjadi angka braille dan bagaimana membuat kalkulator suara untuk tuna netra menggunakan ISD 2590.

\section{PERANCANGAN SISTEM}

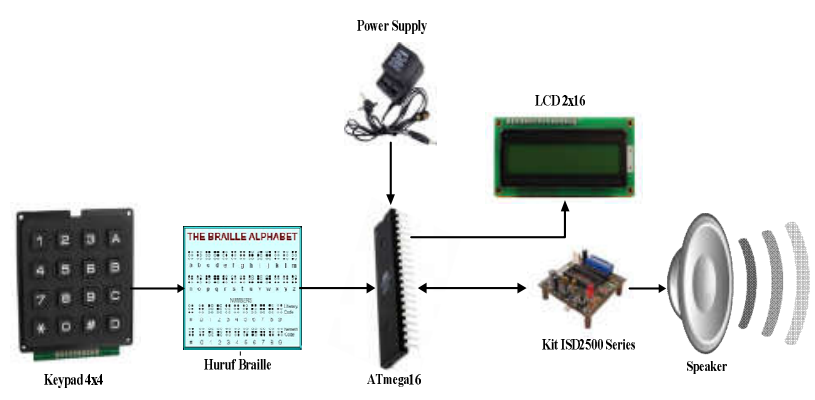

Gambar 1. Diagram Blok Perancangan

Dari sistem diagram blok di atas dapat dijelaskan bahwa keypad sebagai masukan mikrokontroler ATmega16. Mikrokontroler ATmega 16 digunakan untuk memproses masukan dari keypad yang berupa operasi bilangan. Sedangkan ISD 2590 digunakan sebagai keluaran suara berdasarkan penekanan pada keypad, apabila keypad ditekan angka "satu" maka ISD 2590 akan mengeluarkan suara "satu". LCD merupakan keluaran dari mikrokontroler ATmega 16 yang digunakan untuk menampilkan operasi bilangan.

Rangkaian ISD 2590 digunakan untuk mengeluarkan suara sesuai dengan angka yang ditekan pada keypad. Perekaman suara dilakukan secara manual yaitu dengan menggunakan microphone dan mengatur alamat pada setiap kata yang diucapkan menggunakan dip switch A0 - A7.

Prosedur cara melakukan perekaman suara pada ISD 2590 adalah sebagai berikut:

1. Hubungkan rangkaian ISD 2590 dengan catu daya 5 volt.

2. Terlebih dahulu kita set jumper 1 (JP1) pada posisi record dengan cara dihubungkan (short).

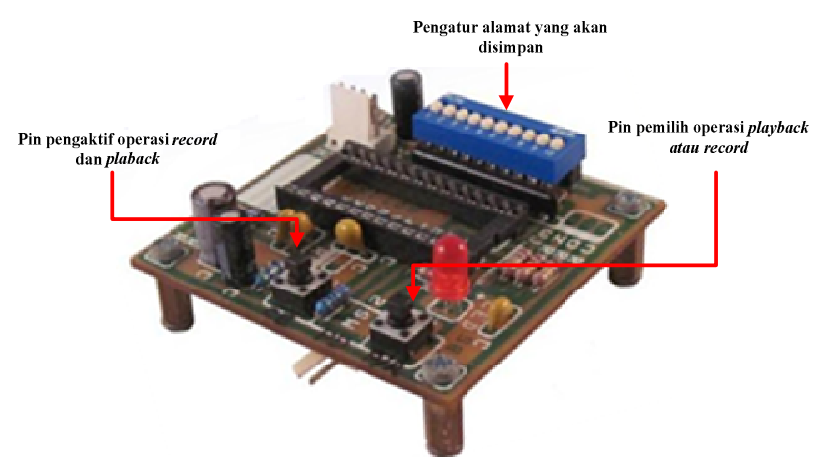

Gambar 2. Rangkaian ISD 2590 untuk melakukan perekaman

Gambar 2 adalah rangkaian ISD 2590 yang digunakan sebagi media perekaman dan penyimpanan data hasil perekaman. Adapun prosedur untuk mendengarkan hasil rekaman adalah sebagai berikut:

1. Terlebih dahulu kita set jumper 1 (JP1) pada posisi play dengan cara dibuka (open).

2. Tentukan alamat untuk suara yang akan dimainkan ( misalnya kata 'satu' di alamat 00011110 biner) dengan mengeset dipswitch mulai dari atas (A0) sampai bawah (A7) on,off,off,off,off,on,on,on. 
3. Buka (open) jumper 2 (JP2).

4. Suara yang disimpan akan terdengar.

5. Untuk mendapatkan alamat suara (voice address) yang telah bervariasi, ulangi dari langkah awal kemudian set dip switch dengan alamat yang berbeda.

6. Tentukan alamat untuk suara yang akan direkam (misalnya kata 'satu' di alamat 00011110 biner) dengan mengeset dipswitch mulai dari atas (A0) sampai bawah (A7) on, off, off, off, off, on, on, on.

7. Hubungkan sambungan JP1 dan JP2 untuk memulai proses perekaman dengan menggunakan microphone, dan untuk mengakhiri proses perekaman lepaskan sambungan JP1 dan JP2.

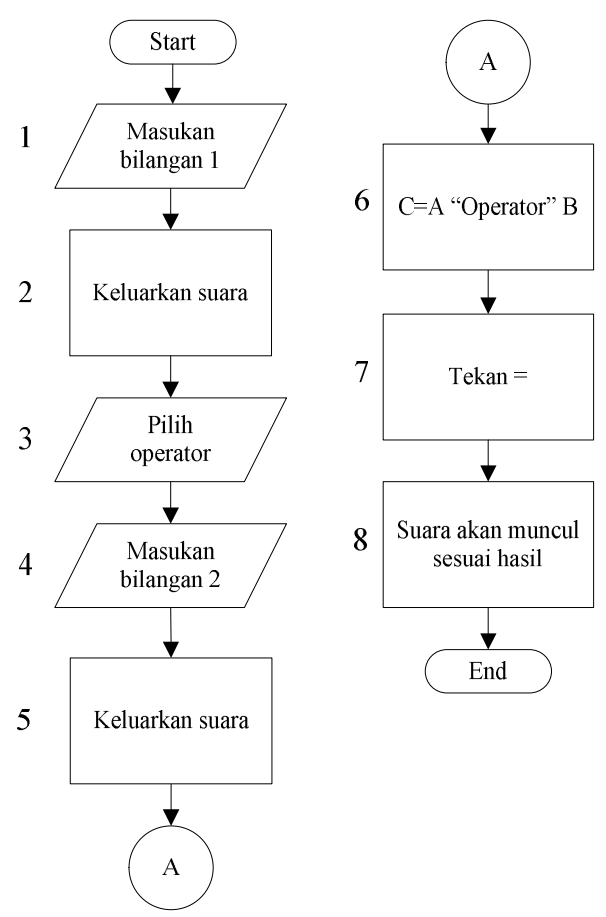

Gambar 3. Diagram alir keseluruhan sistem

Gambar 3 adalah diagram alir sistem ini adapun penjelasan tentang cara kerja dari diagram alir secara keseluruhan adalah sebagai berikut:

1. Masukan bilangan pertama dengan cara menekan pada keypad baik itu bilangan satuan,puluhan, ribuan, dll. Di bawah ini adalah potongan program untuk masukan bilangan pertama.

memori=atof (nilai) ;

konversikan dari array ke float

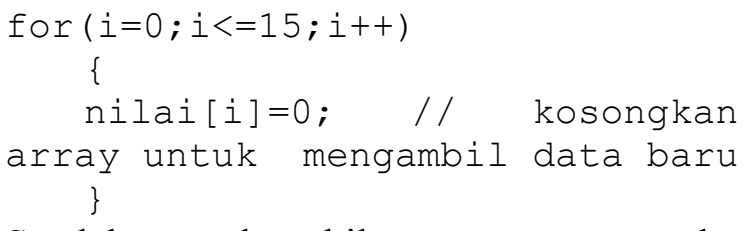

2. Setelah menekan bilangan pertama maka rangkaian ISD 2590 akan mengeluarkan suara sesuai dengan penekanan pada keypad, contoh penekan angka "7". Di bawah ini adalah potongan program sesuai dengan penekan pada bilangan pertama.

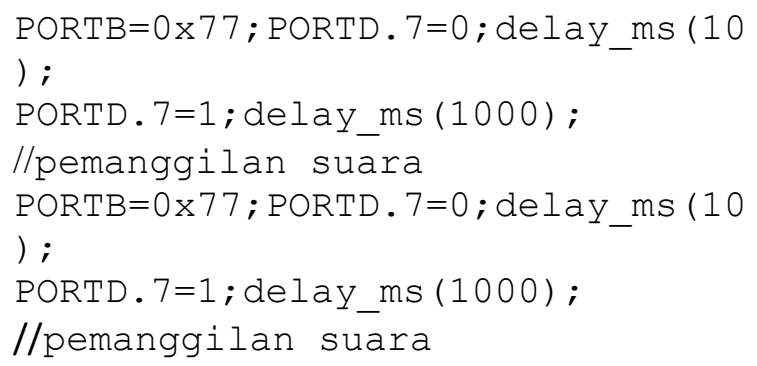

3. Kemudian pilih operator penjumlahan, pengurangan, perkalian, maupun pembagian. Di bawah ini adalah potongan program untuk memilih operator.

fungsi='+' ; // ingatkan bahwa

fungsi aritmatik adalah fungsi penjumlahan

\section{lcd_putchar $(y)$;}

4. Setelah memilih operator kemudian masukan bilangan kedua sesuai dengan keingginan. Di bawah ini adalah potongan program untuk bilangan kedua.

nilai2=atof (nilai); //

konversikan dari array ke float untuk bilangan kedua

5. Setelah bilangan kedua ditekan kemudian akan muncul suara sesuai dengan penekanan pada bilangan kedua.

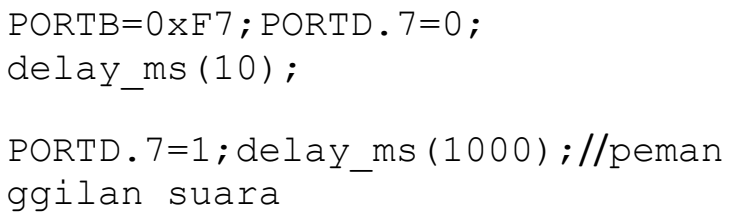

6. Maksud dari $\mathrm{C}=\mathrm{A}$ "operator" $\mathrm{B}$ yaitu $\mathrm{A}$ adalah bilangan pertama, operator adalah 
penjumalahan, pengurangan, perkalian, atau pembagian dan $\mathrm{B}$ adalah bilangan kedua.

7. Kemudian tekan $(=)$ untuk mengetahui hasil dari $\mathrm{C}=\mathrm{A}$ "operator" $\mathrm{B}$. Berikut adalah potongan programnya.

ftoa (hasil, 2, GG) ; // kembalikan

ke string untuk ditampilkan

pada LCD

lcd_putchar ('=');

lcd_puts (GG) ;

8. Setelah menekan sama dengan kemudian akan mucul suara sesuai dengan hasil yang tertera pada LCD 2x16.

\section{HASIL DAN PEMBAHASAN}

\section{A. Pengujian Pengalamatan Suara pada ISD2590}

Tujuan dilakukannya pengujian rangkaian perekam suara ISD 2590 yaitu mengisi suara dan menentukan alamat suara (voice address) yang bervariasi pada IC ISD 2590, serta menguji keberhasilan perekam dan pemutar suara pada rangkaian ISD 2590. Saklar dip switch digunakan untuk mengatur berbagai macam variasi alamat suara yang akan direkam. Bentuk kalkulator elektronik untuk penyandang tuna netra ini dapat dilihat pada Gambar 4.

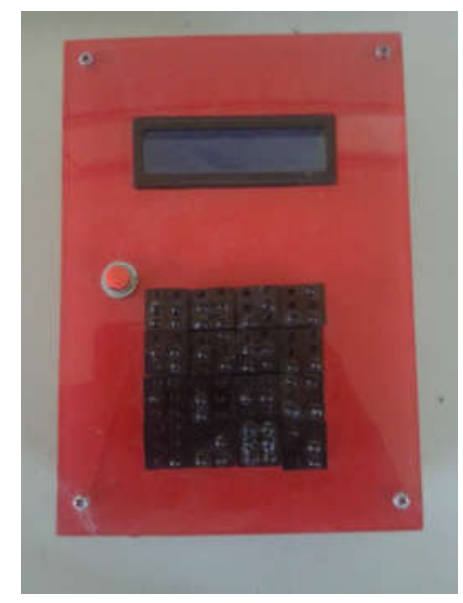

Gambar 4. Kalkulator Braille

Tabel 1 merupakan contoh pengalamatan suara yang disimpan pada IC ISD 2590 yang nantinya setiap alamat tersebut akan diolah pada mikrokontroler ATmega 16. Setelah alamat tersebut dipanggil oleh mikrokontroler kemudian speaker akan mengeluarkan sesuai dengan penekanan tombol pada keypad $4 \times 4$.

Tabel 1. Pengalamatan suara pada ISD 2590

\begin{tabular}{|c|c|c|}
\hline Biner & Hexa & $\begin{array}{l}\text { Suara } \\
\text { Direkam }\end{array}$ \\
\hline 00111000 & $\mathrm{C} 7$ & "Satu" \\
\hline 00001000 & F7 & "Dua" \\
\hline 00010000 & $\mathrm{EF}$ & “Tiga” \\
\hline 11011000 & 27 & "Sembilan" \\
\hline 00110000 & $\mathrm{CF}$ & "Nol" \\
\hline 01101000 & 97 & "Se" \\
\hline 01011000 & A7 & "Koma" \\
\hline 10011000 & 67 & "Puluh" \\
\hline 10101000 & 57 & "Belas" \\
\hline 01111000 & 87 & "Ratus" \\
\hline 01110000 & $8 \mathrm{~F}$ & "Ribu" \\
\hline 10110000 & $4 \mathrm{~F}$ & "Juta" \\
\hline 11110000 & $0 \mathrm{~F}$ & "Mines" \\
\hline 01010000 & $\mathrm{AF}$ & "Tambah" \\
\hline 01100000 & $9 \mathrm{~F}$ & "Kali" \\
\hline 10100000 & $5 \mathrm{~F}$ & "Bagi” \\
\hline 11000000 & $3 \mathrm{~F}$ & "Sama dengan" \\
\hline
\end{tabular}

Maksud dari alamat suara 0b00111000 yaitu dip switch 4, 5, 6 dihubungkan pada posisi off, artinya ISD 2590 mendapatkan sinyal high pada dip swtich 4,5,6. Sama halnya dengan 0b00001000 dip switch 1-8 pada posisi (on, on, on, on, off, on, on, on) atau ISD 2590 mendapatkan sinyal (low, low, low, low, high, low, low, low). Saat melakukan perekaman Pin CE (Chip Enable) dan P/R (Play/Record) diberikan kondisi low atau "0". Dan untuk melakukan pemutaran suara Pin CE diberikan kondisi low dan $\mathrm{P} / \mathrm{R}$ dikondisikan high

Hasil dari pengujian operasi bilangan penjumlahan menunjukan hasil yang sesuai antara operasi bilangan, suara yang dihasilkan, dan angka yang ditampilkan pada LCD 2x16. 
Tabel 2. Hasil Pengujian Operasi Bilangan Penjumlahan

\begin{tabular}{|c|c|c|}
\hline $\begin{array}{c}\text { Operasi } \\
\text { bilangan }\end{array}$ & $\begin{array}{l}\text { Suara yang } \\
\text { dihasilkan }\end{array}$ & $\begin{array}{c}\text { Angka } \\
\text { pada LCD }\end{array}$ \\
\hline $1+1$ & “Dua” & 2 \\
\hline $10+20$ & "Tiga puluh" & 30 \\
\hline $12+3$ & "Lima belas" & 15 \\
\hline $90+10$ & “Seratus" & 100 \\
\hline $100+1$ & "Seratus satu" & 101 \\
\hline $300+11$ & $\begin{array}{l}\text { "Tiga ratus } \\
\text { sebelas" }\end{array}$ & 311 \\
\hline $555+0$ & $\begin{array}{l}\text { "Lima ratus lima } \\
\text { puluh lima" }\end{array}$ & 555 \\
\hline $777+103$ & $\begin{array}{l}\text { "Delapan ratus } \\
\text { delapan puluh" }\end{array}$ & 880 \\
\hline $645+455$ & “Seribu” & 1000 \\
\hline $700+500$ & "Seribu dua ratus" & 1200 \\
\hline
\end{tabular}

Tabel 3. Hasil Pengujian Operasi Bilangan Pengurangan

\begin{tabular}{|c|c|c|}
\hline $\begin{array}{c}\text { Operasi } \\
\text { bilangan }\end{array}$ & $\begin{array}{c}\text { Suara yang } \\
\text { dihasilkan } \\
\text { "Mines Tiga" }\end{array}$ & $\begin{array}{c}\text { Angka pada } \\
\text { LCD }\end{array}$ \\
\hline $4-7$ & -3 \\
\hline $20-30$ & "Mines Sepuluh" & -10 \\
\hline $75-90$ & $\begin{array}{c}\text { "Mines Lima } \\
\text { belas" }\end{array}$ & -15 \\
\hline $40-73$ & $\begin{array}{c}\text { "Mines Tiga } \\
\text { puluh tiga" }\end{array}$ & -33 \\
\hline $140-440$ & $\begin{array}{c}\text { "MInes Tiga } \\
\text { ratus" }\end{array}$ & -300 \\
\hline $8-309$ & $\begin{array}{c}\text { "Mines Tiga ratus } \\
\text { satu" }\end{array}$ & -301 \\
\hline $450-600$ & $\begin{array}{c}\text { "Mines Seratus } \\
\text { lima puluh" }\end{array}$ & -150 \\
\hline $8-220$ & $\begin{array}{c}\text { "Mines Dua ratus } \\
\text { dua belas" }\end{array}$ & -212 \\
\hline $789-9$ & $\begin{array}{c}\text { "Tujuh ratus } \\
\text { delapan puluh" }\end{array}$ & 780 \\
\hline $182-1$ & $\begin{array}{c}\text { "Seratus delapan } \\
\text { puluh satu" }\end{array}$ & 181 \\
\hline
\end{tabular}

Hasil dari pengujian operasi bilangan pengurangan menunjukan hasil yang sama baiknya dengan operasi bilangan penjumlahan. Operasi bilangan pengurangan menunjukan hasil yang sesuai antara operasi bilangan, suara yang dihasilkan, dan angka yang ditampilkan pada LCD 2x16.

Tabel 4. Hasil Pengujian Operasi Bilangan Perkalian

\begin{tabular}{|c|c|c|}
\hline $\begin{array}{c}\text { Operasi } \\
\text { bilangan }\end{array}$ & $\begin{array}{c}\text { Suara yang } \\
\text { dihasilkan }\end{array}$ & $\begin{array}{c}\text { Angka } \\
\text { pada LCD }\end{array}$ \\
\hline $2 \times 2$ & "Empat" & 4 \\
\hline $4 \times 5$ & "Dua puluh" & 20 \\
\hline $13 \times 1$ & "Tiga belas" & 13 \\
\hline $15 \times 3$ & "Empat puluh lima" & 45 \\
\hline $20 \times 10$ & $\begin{array}{c}\text { "Dua ratus" } \\
\text { "Lima ratus dua } \\
\text { puluh enam" }\end{array}$ & 200 \\
\hline $263 \times 2$ & $\begin{array}{c}\text { "seratus dua puluh } \\
\text { satu" }\end{array}$ & 121 \\
\hline $11 \times 11$ & $\begin{array}{c}\text { "Dua ratus dua } \\
\text { puluh delapan" }\end{array}$ & 228 \\
\hline $69 \times 12$ & \\
\hline
\end{tabular}

Hasil dari pengujian operasi bilangan perkalian menunjukan hasil yang sama baiknya dengan operasi bilangan penjumlahan dan pengurangan. Operasi bilangan perkalian menunjukan hasil yang sesuai antara operasi bilangan, suara yang dihasilkan, dan angka yang ditampilkan pada LCD 2x16.

Tabel 5. Hasil Pengujian Operasi Bilangan Pembagian

\begin{tabular}{|c|c|c|}
\hline $\begin{array}{c}\text { Operasi } \\
\text { bilangan }\end{array}$ & $\begin{array}{c}\text { Suara yang } \\
\text { dihasilkan }\end{array}$ & $\begin{array}{c}\text { Angka } \\
\text { pada LCD }\end{array}$ \\
\hline $12 / 2$ & "Enam" & 6 \\
\hline $49 / 7$ & "Tujuh" & 7 \\
\hline $75 / 5$ & "Lima belas" & 15 \\
\hline $255 / 5$ & "Lima puluh satu" & 51 \\
\hline & & 75 \\
\hline $150 / 2$ & "Tujuh puluh lima" & 71 \\
\hline & & 20 \\
\hline $155 / 5$ & "Tiga puluh satu" & 31 \\
\hline $10 / 2$ & "Dua puluh" & 25 \\
\hline $1500 / 3$ & "Dua puluh lima" & 250 \\
\hline
\end{tabular}


Hasil dari pengujian operasi bilangan pembagian menunjukan hasil yang sama baiknya dengan operasi bilangan penjumlahan, pengurangan, dan perkalian. Operasi bilangan perkalian menunjukan hasil yang sesuai antara operasi bilangan, suara yang dihasilkan, dan angka yang ditampilkan pada $L C D 2 \times 16$.

Tabel 5. Hasil Pengujian Bilangan Pecahan

\begin{tabular}{|c|c|c|}
\hline $\begin{array}{c}\text { Operasi } \\
\text { bilangan }\end{array}$ & $\begin{array}{l}\text { Suara yang } \\
\text { dihasilkan }\end{array}$ & $\begin{array}{c}\text { Angka } \\
\text { pada } L C D\end{array}$ \\
\hline $2 / 3$ & $\begin{array}{l}\text { "Nol koma enam } \\
\text { puluh enam" }\end{array}$ & 0,67 \\
\hline $25 / 6$ & $\begin{array}{c}\text { "Empat koma enam } \\
\text { belas" }\end{array}$ & 4,17 \\
\hline $1 / 5$ & “Nol Koma Dua & 0,2 \\
\hline $23 / 9$ & $\begin{array}{l}\text { "Dua koma lima } \\
\text { puluh lima" }\end{array}$ & 2,56 \\
\hline $23 / 3$ & $\begin{array}{l}\text { "Tujuh koma enam } \\
\text { puluh enam" }\end{array}$ & 7,67 \\
\hline $4 / 5$ & $\begin{array}{c}\text { "Nol koma delapan } \\
\text { puluh" }\end{array}$ & 0.80 \\
\hline 999/777 & $\begin{array}{l}\text { "Satu koma dua } \\
\text { puluh delapan" }\end{array}$ & 1,29 \\
\hline $2 / 5$ & $\begin{array}{l}\text { "Nol koma empat } \\
\text { puluh" }\end{array}$ & 0,40 \\
\hline $1 / 2$ & $\begin{array}{c}\text { "Nol koma lima } \\
\text { puluh" }\end{array}$ & 0,50 \\
\hline $12 / 5$ & $\begin{array}{c}\text { "Dua koma empat } \\
\text { puluh" }\end{array}$ & 2,40 \\
\hline
\end{tabular}

Hasil dari pengujian bilangan pecahan menunjukan hasil yang sama baiknya dengan operasi bilangan penjumlahan, pengurangan, perkalian, dan pembagian.

\section{KESIMPULAN}

Kesimpulan yang dapat ditarik pada proses perancangan dan pembuatan sampai analisa di Tugas Akhir ini adalah sebagai berikut:

1. Alat ini bisa operasi bilangan bulat mulai dari 1-9999 dan bilangan pecahan mulai dari 0,00-9999,99. Tetapi ada beberapa bilangan pecahan yang tidak sesuai antara hasil yang ditampilkan oleh LCD 2x16 dengan suara yang dihasilkan, dikarenakan pembulatan angka dibelakang koma.

2. Kalkulator ini hanya mampu melakukan operasi bilangan penjumlahan, pengurangan, perkalian, pembagian baik itu bilangan bulat maupun pecahan.

3. Kalkulator ini hanya bisa melakukan operasi aritmatika sederhana, belum di rancang untuk operasi aritmatika tingkat lanjut sepert operasi trogonometri, bilangan polar dan rectangular.

Fungsi dari alat ini diharapkan bisa diperluas lagi, agar tidak hanya bisa melakukan 4 operasi bilangan saja. Diharapkan aplikasi dari alat ini bukan hanya untuk melakukan perhitungan yang sederhana, tetapi diharapkan bisa untuk melakukan bilangan perhitungan yang rumit seperti perhitungan sinus, cosinus, tangen dan sebagainya.

\section{DAFTAR PUSTAKA}

[1] Andrianto Heri. 2008. Pemrograman Mikrokontroler AVR ATmega16. Bandung: Informatika Bandung.

[2] ATMEL CORPORATION. 2005. AVR245: Code Lock with $4 \times 4$ Keypad and I2C ${ }^{\mathrm{TM}}$ $L C D$.

[3] Datasheet. 2006. Fungsi Akses Keypad untuk Microcontroller AVR dengan bahasa $C$ (CodeVisionAVR).

[4] Datasheet, 2010. M1632 MODULE LCD $16 X 2$ BARIS (M1632).

[5] Innovative Electronics. 2009. EMS (Embedded Module Series) LCD Display.

[6] Maryanto Hendra. 2010. Pembuatan Prototipe Pintu Otomatis Satu Arah Berbasis Mikrokontroler ATmega 8535 Menggunakan Double IR. Fakultas Matematika Dan Ilmu Pengetahuan Alam Universitas Sebelas Maret Surakarta.

[7] Misto. 2009. Termometer Dengan Keluaran Suara Berbasis Mikrokontroler ATmega8535Untuk mengukur Suhu Ruangan.

[8] Muhammad. 2012. Kalkulator Suara dengan Keypad Braille Berbasis Mikrokontroler ATmega128 sebagai Alat 
Bantu Menghitung bagi Tunanetra. Laporan Proyek Akhir FT UNY.

[9] Rahmawati Rafika. 2007. Makalah Pengabdian Masyarakat di SD Budi Mulia Dua. Universitas Negeri Yogyakarta.

[10] Parangin-angin Bisman. 2009. Perancangan Peralatan Penjawab Telefon Otomatis Berbasis Mikrokontroler. Fakultas Matematika dan Ilmu Pengetahuan Alam Universitas Sumatera Utara.

[11] Winbond Electronics Corp. 2003. Single Chip Multiple-Messages Voice Record/Playback Device ISD2590/75/90/120-Second Duration. 